\title{
MUNICIPAL WASTEWATER TREATMENT WITH BENTONITE FROM MILOS ISLAND, GREECE
}

\author{
Bourliva A. ${ }^{1}$, Michailidis K. ${ }^{1}$, Sikalidis C. ${ }^{2}$, Filippidis A. ${ }^{1}$, \\ and Apostolidis N. ${ }^{3}$ \\ ${ }^{1}$ Aristotle University of Thessaloniki, Faculty of Sciences, Department of Mineralogy-Petrology-Economic \\ Geology, 54124 Thessaloniki, Greece, annab@geo.auth.gr \\ ${ }^{2}$ Aristotle University of Thessaloniki, Department of Chemical Engineering, 54124 Thessaloniki, Greece \\ ${ }^{3}$ Water \& Sewage Municipal Public Utility of Kilkis City, 1st klm. Kilkis-Xirovrisi, 61100 Kilkis, Greece
}

\begin{abstract}
Bentonite clay minerals belonging to the smectite group have a wide range of chemical and industrial uses. The structure and chemical composition, exchangeable ion type and small crystal size of smectite are responsible for several properties, including a large chemically active surface area and a high cation exchange capacity. A wastewater treatment using bentonite from Milos island, Greece, was investigated. Raw wastewater sample (influent) from the wastewater treatment plant (WTP) of the city of Kilkis, Northern Greece was treated using bentonite in conjunction with chemical coagulants (polyaluminium chloride-PAC and cationic polyelectrolyte), in batch type experiments. The removal of suspended solids (SS), chemical oxygen demand (COD), nitrate ion, ammonium ion, phosphate ion, and toxic metals were evaluated. The treatment gave overflowed clear water improved concerning the quality parameters. The bentonite adding prior to flocculation resulted in effective removal of heavy metals such as chromium and copper. Additionally, the bentonite removed nitrogen compounds with relatively high efficiency, while the clay presence highly improved the COD removal. The quality parameters after treatment were improved fulfilling the requirements for disposition as downstream, irrigation, swimming and fish waters.
\end{abstract}

Keywords: wastewater treatment, bentonite, influent, chemical coagulants.

\section{Introduction}

Due to the rapid development in technology and urbanization, increasing amounts of industrial, agricultural, and domestic wastes are discharged to receiving waters. Generally, they are discharged to the nearest water sources such as rivers, lakes and seas. Wastewater treatment plants (WTPs) are expected to control the quality of the municipal wastewater (including industrial hazardous wastes) before being discharged into the nearby water sources (Chen et al., 2002).

The need for water re-use has made the effluents from municipal WTPs to be considered as a valuable resource and integrated into the available water supply. The effluents from these plants, however, usually contain some impurities, such as suspended matter, residues of stable organic materials, and refractory matter, which can cause undesirable colour, taste, and odour. Besides they contain nutrients such as phosphates and nitrogenous materials that cause eutrophication in receiving waters. 
Table 1. Chemical and mineralogical composition of bentonite with specific surface area and cation exchange capacity value.

\begin{tabular}{|c|c|c|c|c|c|c|c|c|c|c|c|}
\hline Sample & $\mathrm{SiO}_{2}$ & $\mathbf{A l}_{2} \mathbf{O}_{3}$ & $\mathrm{TiO}_{2}$ & $\mathrm{MnO}$ & $\mathrm{Fe}_{2} \mathrm{O}_{3} \mathrm{t}$ & MgO & $\mathrm{CaO}$ & $\mathrm{Na}_{2} \mathrm{O}$ & $\mathbf{K}_{2} \mathbf{O}$ & $\mathrm{P}_{2} \mathrm{O}_{5}$ & LOI \\
\hline \multirow{5}{*}{ Bentonite } & 58.75 & 17.09 & 0.62 & 0.035 & 4.00 & 3.52 & 3.56 & 0.95 & 0.75 & 0.08 & 10.72 \\
\hline & $\begin{array}{c}\mathrm{Ba} \\
(\mu \mathrm{g} / \mathrm{g})\end{array}$ & $\begin{array}{c}\mathrm{Co} \\
(\mu \mathrm{g} / \mathrm{g})\end{array}$ & & & $\underset{(\mu \mathrm{g} / \mathrm{g})}{\mathrm{Cu}}$ & $\underset{(\mu \mathrm{g} / \mathrm{g})}{\mathrm{Ni}}$ & $\underset{(\mu \mathrm{g} / \mathrm{g})}{\mathrm{Pb}}$ & $\begin{array}{r}\mathbf{R b} \\
(\mu \mathrm{g} / \mathrm{g}\end{array}$ & & $\begin{array}{l}\mathrm{Sr} \\
\mathrm{ug} / \mathrm{g})\end{array}$ & $\underset{(\mu \mathrm{g} / \mathrm{g})}{\mathrm{Zn}}$ \\
\hline & 386 & 22 & & 3 & 26 & - & - & 49 & & 95 & 42 \\
\hline & \multicolumn{2}{|c|}{$\begin{array}{c}\text { CEC } \\
(\mathrm{meq} / \mathbf{1 0 0 g})\end{array}$} & & & \multicolumn{7}{|c|}{ Mineralogical Composition } \\
\hline & \multicolumn{2}{|c|}{104.35} & \multicolumn{2}{|c|}{66.41} & \multicolumn{7}{|c|}{ Smectite, Calcite, Amorphous, Mica (tr), Pyrite (tr) } \\
\hline
\end{tabular}

Flocculation and adsorption are typical examples of treatment processes. Recently, low cost materials, including rice-husk, maple sawdust, soya cake, coal ash, peat and bone char, have been investigated as adsorbents for wastewater treatment (Ahsan et al., 2001; Daneshvar et al., 2002; Ringqvist et al., 2002; Daifullah et al., 2003; Yu et al., 2003; Kirk et al., 2003). Additionally, the purification of industrial and urban wastewaters using a HEU-type zeolite (clinoptilolite) has been successfully applied (Filippidis et al., 2008a, Filippidis et al.,2008b).

Clay minerals have great potential as inexpensive and efficient adsorbents for wastewater treatment due to their large reserves, chemical and mechanical stability, high specific surface area, and structural properties. Part of the organic matter present in the effluent may be adsorbed on clay minerals, which have a large active surface area available for adsorption, especially for compounds containing amines, amides, and polysaccharides (Greenland, 1965). In this way, the adsorbed complex will cause removal of various compounds from the liquid during a flocculation step.

In the present study raw bentonite samples from Milos island were used in combination with chemical coagulants in the treatment of municipal wastewater. Bentonite is a natural clay formation consisting mainly of montmorillonite which belongs to the 2:1 smectite clay mineral group. The basic structural unit is composed of two tetrahedrally coordinated sheets of silicon ions surrounding a sandwiched octahedrally coordinated sheet of aluminum ions. The isomorphous substitution of $\mathrm{Al}^{3+}$ for $\mathrm{Si}^{4+}$ in the tetrahedral layer and $\mathrm{Mg}^{2+}$ for $\mathrm{Al}^{3+}$ in the octahedral layer results in a net negative surface charge on the clay (Luckham and Rossi, 1999). Compared with other clay types, it has excellent sorption properties and possesses sorption sites available within its interlayer space as well as on the outer surface and edges (Tabak et al., 2007).

\section{Materials and Methods}

\subsection{Characterization of bentonite}

The raw bentonite was kindly provided by the S\&B Industrial Minerals S.A., Milos island, Greece. The sample was air-dried, ground and sieved. The $<63 \mu \mathrm{m}$ particle size fraction was used in the experiments. The chemical composition of bentonite was determined by AAS (Perkin Elmer 901A). X-ray diffraction (XRD) analysis of the sample was carried out with a Philips PW 1710 diffractometer using $\mathrm{CuK} \alpha$ radiation, in the $2 \theta$ angle range from $3^{\circ}$ to $63^{\circ}$. The cation exchange capacity (CEC) and specific surface area (SSA) were obtained by the ammonium acetate method (Alexiades and Jackson, 1966) and multipoint BET $\mathrm{N}_{2}$ adsorption method. The mineralogical and chemical 


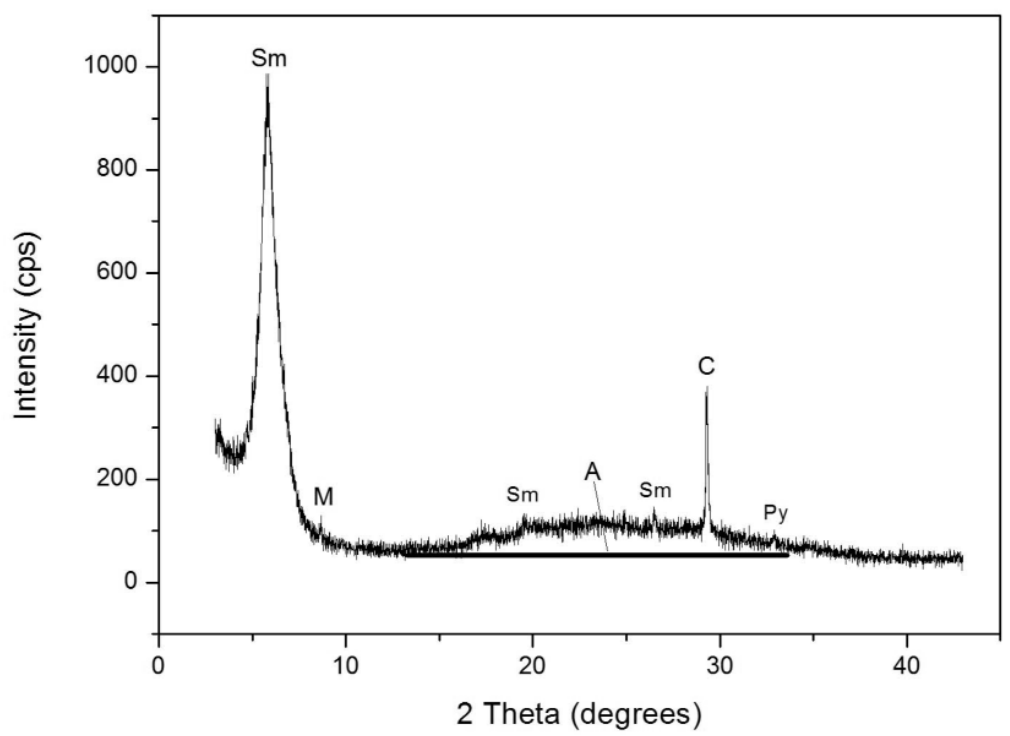

Fig. 1: X-ray diffraction pattern of bentonite sample (A: Amorphous, C: Calcite, M:Mica, Sm: Smectite, Py: Pyrite).

compositions of the bentonite are presented in Table 1. The X-ray diffraction pattern of the bentonite sample is shown in Figure 1.

\subsection{Sampling the wastewater samples}

The raw wastewater samples (influent) were obtained from the wastewater treatment plant (WTP) of the city of Kilkis. The WTP serves about 26,000 residents by treating daily $7,500-10,000 \mathrm{~m}^{3}$ of municipal wastewaters. About $5-10 \%$ of the total flow is contributed by small enterprises. The treatment process includes screening, grit removal, primary sedimentation with the use of chemical coagulants (polyaluminium chloride-PAC and cationic polyelectrolyte), conventional activated sludge treatment, and effluent disinfection with UV-radiation. The quality of the influent is presented in Table 2.

\subsection{Treatment Procedure}

Municipal wastewaters were treated with bentonitic clay at room temperature, in batch type experiments. The treatment process proceeded with rapid mixing of $300 \mathrm{ml}$ raw wastewater samples with $7.5 \mathrm{~g}$ of bentonite at $400 \mathrm{rpm}$ for $60 \mathrm{~min}$, slow mixing of $40 \mathrm{rpm}$ for $30 \mathrm{~min}$ and then standstill for 20 min. Polyaluminium chloride (PAC) and cationic polyelectrolyte were added as coagulant aids during the slow mixing step. For comparison reasons the same process was conducted without the addition of the bentonite. The bentonite amount $(7,5 \mathrm{~g})$ added was chosen as the optimum (with the higher removal percentage) after experimental trials with various amounts of this material. The supernatant was filtered through $0.45 \mu \mathrm{m}$ and analyzed. All the essays were conducted in triplicate and only mean values are presented. 
Table 2. Quality of the raw wastewater (influent) from the Kilkis wastewater treatment plant.

\begin{tabular}{|l|c|c|}
\hline Constituents & Units & $\begin{array}{c}\text { Influent } \\
\text { (Raw Wastewater) }\end{array}$ \\
\hline Temperature & ${ }^{\circ} \mathrm{C}$ & 23.6 \\
\hline $\mathbf{p H}$ & & 8.71 \\
\hline Conductivity & $\mu \mathrm{S} / \mathrm{cm}$ & 1487 \\
\hline Colour & $\mathrm{Pt} / \mathrm{Co}$ & 2375 \\
\hline TSS & $\mathrm{mg} / \mathrm{L}$ & 360 \\
\hline $\mathbf{C O D}$ & $\mathrm{mg} / \mathrm{L}$ & 742 \\
\hline $\mathbf{N O}_{3}-\mathbf{N}$ & $\mathrm{mg} / \mathrm{L}$ & 14.2 \\
\hline $\mathbf{N O}_{2}-\mathbf{N}$ & $\mathrm{mg} / \mathrm{L}$ & 0.043 \\
\hline $\mathbf{N H}_{4}-\mathbf{N}$ & $\mathrm{mg} / \mathrm{L}$ & 138.50 \\
\hline $\mathbf{P O}_{4}{ }^{3-}$ & $\mathrm{mg} / \mathrm{L}$ & 4.77 \\
\hline $\mathbf{C r}_{\text {total }}$ & $\mathrm{mg} / \mathrm{L}$ & 0.05 \\
\hline $\mathbf{C u}$ & $\mathrm{mg} / \mathrm{L}$ & 0.30 \\
\hline $\mathbf{M n}$ & $\mathrm{mg} / \mathrm{L}$ & 0.241 \\
\hline $\mathbf{N i}$ & $\mathrm{mg} / \mathrm{L}$ & 0.281 \\
\hline $\mathbf{Z n}$ & $\mathrm{mg} / \mathrm{L}$ & 0.67 \\
\hline
\end{tabular}

TSS: Total Suspended Solids, COD: Chemical Oxygen Demand

\subsection{Analytical Methods}

Electrical conductivity and $\mathrm{pH}$ were measured with an electrode (CDM210, Radiometer, Copenhagen) and a combination electrode, respectively, at $25^{\circ} \mathrm{C}$. The concentration of total suspended solids was determined by immediately filtering the samples through a 0.45 micron filter paper. The filters were weighed before the filtration and subsequently dried and weighed again after the filtration to determine the concentration of suspended solids Analysis of colour, phosphate $\left(\mathrm{PO}_{4}^{3-}\right)$, ammonia $\left(\mathrm{NH}_{4}^{+}\right)$, nitrate $\left(\mathrm{NO}_{3}{ }^{-}\right)$, nitrite $\left(\mathrm{NO}_{2}{ }^{-}\right)$, and the metals $\mathrm{Cr}($ total $), \mathrm{Cu}^{2+}, \mathrm{Mn}^{2+}$ and $\mathrm{Ni}^{2+}$ were performed using a HACH DR/2000 spectrophotometer.

\section{Results and Discussion}

The use of bentonite in conjunction with chemical coagulants in the treatment of municipal wastewaters was investigated. The results are presented in Table 3 and Figure 1. The treated wastewaters resulted in clear overflowed waters, free of odours and highly improved quality parameters.

Treatment of the municipal sewages with $\mathrm{pH} 8.71$ resulted in a decrease of $\mathrm{pH}$ value to 6.72 and 6.61 with and without the addition of bentonite in the process, respectively.

Reduction of suspended solids (SS) plays a significant role in modern wastewater treatment, since the SS serves as an adsorbent for heavy metals and polychlorinated biphenyls (PCBs) (Rosenwinkel et al., 2001). Total suspended solids were effectively removed (99\%) with no bentonite addition, due to flocculation. The bentonite added in the process made no significant difference in the TSS removal. 
Table 3. Quality of the wastewaters after the treatment with and without the addition of bentonite.

\begin{tabular}{|c|c|c|c|c|c|}
\hline \multirow[b]{2}{*}{ Constituents } & \multicolumn{2}{|c|}{$\begin{array}{c}\text { Treatment } \\
\text { Without Bentonite }\end{array}$} & \multicolumn{3}{|c|}{$\begin{array}{c}\text { Treatment } \\
\text { With Bentonite }\end{array}$} \\
\hline & $\begin{array}{c}\text { Treated } \\
\text { Wastewater }\end{array}$ & $\pm \%$ & $\begin{array}{c}\text { Treated } \\
\text { Wastewater }\end{array}$ & $\pm \%$ & $\begin{array}{c} \pm \% \text { Difference } \\
\text { With the } \\
\text { Bentonite } \\
\text { Addition }\end{array}$ \\
\hline pH & $6.61 \pm 0.1$ & -24.11 & $6.72 \pm 0.2$ & -22.85 & +1.3 \\
\hline $\mathrm{EC}(\boldsymbol{\mu S} / \mathrm{cm})$ & $1929 \pm 3$ & -29.72 & $2050 \pm 2$ & -37.86 & +8.1 \\
\hline Colour $(\mathrm{Pt} / \mathrm{Co})$ & $32 \pm 0.5$ & -98.65 & $6 \pm 0.1$ & -99.75 & +1.10 \\
\hline TSS (mg/L) & $3 \pm 0.1$ & -99.17 & $1 \pm 0.1$ & -99.72 & +0.56 \\
\hline COD (mg/L) & $250 \pm 2$ & -66.31 & $146 \pm 2$ & -80.32 & +14.02 \\
\hline $\mathrm{NO}_{3}-\mathrm{N}(\mathrm{mg} / \mathrm{L})$ & $5.40 \pm 0.05$ & -61.97 & $1.90 \pm 0.02$ & -86.62 & +24.65 \\
\hline $\mathrm{NO}_{2}-\mathrm{N}(\mathrm{mg} / \mathrm{L})$ & $0.018 \pm 0.007$ & -58.14 & $0.010 \pm 0.003$ & -76.74 & +18.60 \\
\hline $\mathrm{NH}_{4}-\mathrm{N}(\mathrm{mg} / \mathrm{L})$ & $126.20 \pm 0.05$ & -30.01 & $82.40 \pm 0.08$ & -54.30 & +24.29 \\
\hline $\mathrm{PO}_{4}^{3-}(\mathrm{mg} / \mathrm{L})$ & $0.44 \pm 0.01$ & -90.78 & $0.39 \pm 0.01$ & -91.82 & +1.05 \\
\hline $\mathrm{Cr}_{\text {total }}(\mathrm{mg} / \mathrm{L})$ & $0.02 \pm 0.01$ & -60.00 & $0.01 \pm 0.01$ & -80 & +20 \\
\hline $\mathrm{Cu}(\mathrm{mg} / \mathrm{L})$ & $0.11 \pm 0.01$ & -63.33 & $0.07 \pm 0.01$ & -76.67 & +13.33 \\
\hline $\operatorname{Mn}(\mathrm{mg} / \mathrm{L})$ & $0.041 \pm 0.005$ & -82.99 & $0.037 \pm 0.005$ & -84.65 & +1.66 \\
\hline $\mathrm{Ni}(\mathrm{mg} / \mathrm{L})$ & 0 & -100 & 0 & -100 & 0 \\
\hline $\mathrm{Zn}(\mathrm{mg} / \mathrm{L})$ & $0.21 \pm 0.03$ & -68.66 & $0.50 \pm 0.03$ & -25.37 & -43.28 \\
\hline
\end{tabular}

Each value is the mean of three readings \pm standard deviation.

The discharge of untreated wastewater containing high levels of organic pollutants into river water affects the suitability of river water for human use and it stimulates the growth of algae and aquatic plants (Kuroda et al., 1997). Hence, various treatment methodologies have been used for the removal of organic load from wastewater. Most of them are complicated and time-consuming, except for adsorption methods, which are of low cost and easy to use. A COD removal of about $66 \%$ occurs as a result of the treatment with no clay added, due to flocculation. The presence of bentonite notably improves the removal of COD. Almost $80 \%$ of the total COD can be removed by treating with chemical coagulants after the addition of clay. The bentonite alone, when added to the influent removed $14 \%$ of the total COD. The more efficient removal of COD by bentonite is related to the effective adsorption of organic matter in the large surface area of the clay (Greenland, 1965).

The presence of excess nitrogen and its compounds has a negative impact on the environment. Nitrogenous compounds play an important role in water pollution and it is well known that they cause serious diseases (Balci and Dinçel, 2002). Therefore, the control of them in water has vital importance. In the treatment process without the bentonite, the removal efficiencies of nitrate, nitride and ammonium ion from the wastewater, were relatively low (30-62\%). Bentonite adding prior to flocculation highly improved the removal of the nitrogen compounds. The bentonite itself removes $25 \%$ of nitrate ion, $19 \%$ of nitride ion and $24 \%$ of ammonium ion. Consequently, nitrogen compounds are 


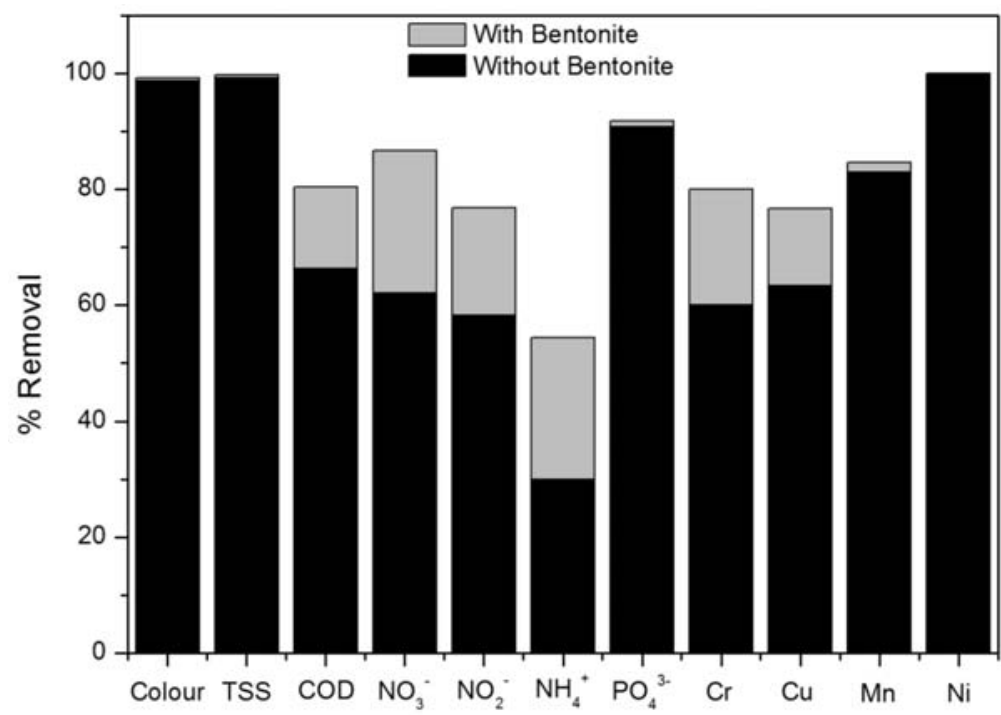

Fig. 2: Removal percentage of influent constituents with and without the presence of bentonite in the treatment process.

effectively removed by the bentonitic clay. $\mathrm{NO}_{3}{ }^{-}$and $\mathrm{NO}_{2}{ }^{-}$ions were basically removed by ion exchange or by physical adsorption, while $\mathrm{NH}_{4}{ }^{+}$ions were removed by cation exchange processes after bentonite addition (Grimshaw and Harland, 1975; Ahsan et al., 2001).

Phosphorus is a critical nutrient for many biological systems, including the production of food. In a soluble form, phosphate has good surfactant properties and is used extensively in cleaners, detergents and washing soaps. During its widespread commercial use, its ability to stimulate the growth of algae in water systems has become very apparent. Therefore, the amounts of phosphate in domestic and industrial wastewaters need to be controlled using the either chemical or biological techniques (Galarneau and Gehr, 1997; Kirk et al., 2003). The chemical coagulants used in the treatment process showed high efficiencies for removal of phosphate ion. The bentonite addition in the treatment resulted in a slight difference $(\sim 1 \%)$ in the phosphate ion removal.

Chromium, copper, manganese, nickel and zinc are commonly known toxic heavy metals and tend to concentrate in environmental systems and in humans. Therefore, the effect of bentonite in conjunction with chemical coagulants in the removal of these heavy metals in wastewater treatment was investigated, as presented in Table 3 and Figure 1. The heavy metal removal efficiencies are relatively high (60-100\%) for the treatment with no bentonite added. The bentonite addition shows a slight difference in the removal of chromium (20\%), copper (13\%) and manganese (1.7\%). Contrary, the clay addition showed an increase in the zinc concentration in the treated wastewater. However, this increase can be attributed to the exchangeable $\mathrm{Zn}$ cation hosted in the bentonitic clay (Table 2). Therefore, for the concentrations of heavy metals tested $(<1 \mathrm{mg} / \mathrm{L})$, the bentonite addition seems to be effective only for the removal of chromium and copper.

The notable effect of bentonitic clay in improving removal of the various components from the influent can be explained by several mechanisms. This hydrophobic colloid, having a large available surface area, adsorbs the products of the reaction between the chemical coagulants like cationic 
polyelectrolyte and anionic components of the influent. The clay particles serve as nuclea for flocculation, resulting in formation of large, rapid settling flocs. Therefore, reaction products that were finely dispersed and could not be made to settle after flocculation (but would be separated by centrifuging) did indeed settle from the suspension in the presence of clay. This means that the main task of the clay is to aid in the settling of the suspended solids. It must also be remind that the clay added to the effluent is in a coagulative state, because of the ionic strength and the high $\mathrm{Ca}^{2+}$ concentration in the latter. The clay suspension approaches instability and it can easily be flocculated (Rebhun et al., 1969).

\section{Conclusions}

The use of bentonite in combination with chemical coagulants for the removal of TSS, COD, nitrogen compounds $\left(\mathrm{NO}_{3}{ }^{-}, \mathrm{NO}_{2}^{-}, \mathrm{NH}_{4}^{+}\right)$, phosphate ion and toxic metals in the treatment of municipal wastewaters was investigated. Treatment resulted to clear overflowed waters, free of odours. The quality parameters of the overflowed water were improved. Bentonite adding prior to flocculation was effective for removal of COD, nitrogen compounds and selected heavy metals such as chromium and copper. The quality parameters in the treated wastewaters are fulfilling the requirements for disposition as downstream, irrigation, swimming and fish waters (Andreadakis et al., 2003; EPA, 2004).

\section{Acknowledgements}

The authors would like to thank the S\&B Industrial Minerals S.A. company which kindly provided the raw bentonite applied in this investigation.

\section{References}

Ahsan, S., Kaneco, S., Ohta, K., Mizono, T., Kani, K., 2001. Use of some natural and waste materials for waste water treatment. Water Res. 35, 3738-3742.

Alexiades, C.A., Jackson, M.L., 1966. Quantitative clay mineralogical analysis of soils and sediments. Clays and Clay Minerals 14, 35-52.

Andreadakis, A., Gavalaki, E., Mamais, D., Tzimas, A., 2003. Wastewater reuse criteria in Greece. Global Nest, 5(1), 9-14.

Balci, S., Dinçel, Y., 2002. Ammonium ion adsorption with sepiolite: use of transient uptake method. Chem. Eng. Process. 41, 79-85.

Chen, J.P., Chua, M.L., Zhang, B., 2002. Effects of competitive ions, humic acid, and pH on removal of ammonium and phosphorus from the synthetic industrial effluent by ion exchange resins. Waste Manage. 22, 711-719.

Daifullah, A.A.M., Girgis, B.S., Gad, H.M.H., 2003. Utilization of agroresidues (rice husk) in small waste water treatment plans. Mater. Lett. 57, 1723-1731.

Daneshvar, N., Salari, D., Aber, S., 2002. Chromium adsorption and Cr (VI) reduction to trivalent chromium in aqueous solutions by soya cake. J. Hazard. Mater. B94, 49-61.

Filippidis, A., Apostolidis, N., Filippidis, S., Paragios, I., 2008. Purification of industrial and urban wastewaters, production of odorless and cohesive zeo-sewage sludge using Hellenic Natural Zeolite. Proceedings of $2^{\text {nd }}$ Intern. Conf. Decentralized Water and Wastewater Treatment Plants, Skiathos, Greece, 403-408.

Filippidis, A., Apostolidis, N., Filippidis, S., Paragios, I., 2008. Purification of urban wastewaters, production of odorless and cohesive zeo-sewage sludge using Hellenic Natural Zeolite. Proceedings of 
$8^{\text {th }}$ Hydrogeological Intern. Congr. Of Greece, 9p (in press).

Galarneau, E., Gehr, R., 1997. Phosphorus removal from wastewater: experimental and theoretical support for alternative mechanisms. Water Res. 31, 328-338.

Greenland J., 1965. Interaction between clays and organic compounds in soils. Part 1. Mechanisms of interaction between clays and defined organic components. Soils Fertil. 38, 415-421.

Grimshaw, R.W., Harland C.E., 1975. Ion-exchange: Introduction to theory and practice. The Chemical Society, London, pp.137.

Kirk, D.W., Charles, Q., Jia, J.Y., Alan, L.T., 2003. Wastewater remediation using coal ash. J. Mater. Cycles Waste Manage. 5, 5-8.

Kuroda, M., Watanbe, T., Umedu, Y., 1997. Simulataneous COD removal and denitrification of wastewater by bio-electro reactors. Water Sci. Technol. 35, 161-168.

Luckham, P.F., Rossi, S., 1999. The colloidal and rheological properties of bentonite suspensions. Adv. Colloid Interface Sci. 82, 43-92.

Rehbun, M., Narkis, N., Wachs, A.M., 1969. Effect of polyelectrolytes in conjuction with bentonitic clay on contaminants removal from secondary effluents. Water Res. 3, 345-355.

Ringqvist, L., Holmgren, A., Öborn, I., 2002. Poorly humified peat as an adsorbent for metals in wastewater. Water Res. 36, 2394-2404.

Rosenwinkel, K.H., Weichgrebe, D., Meyer, H., Wendler, D., 2001. Suspended solids from industrial and municipal origins. Ecotoxicol. Environ. Saf. 50, 135-142.

Tabak, A. Afsin, B., Aygun, S.F., Koksal E., 2007. Structural charactristics of organo-modified bentonites of different origin. J. Therm. Anal. Calorim. 87, 375-381.

U.S. Environmental Protection Agency, 2004. Guidelines for water reuse. EPA/625/R-04/108, Washington D.C., U.S.A.

Yu, L.J., Shukla, S.S., Dorris, K.L., Sukla, A., Margrave, J.L., 2003. Adsorption of chromium from aqueous solutions by mapple sawdust. J. Hazard. Mater. 100, 53-63. 